\title{
Uranium Mimics ER-Dependant Responses Mediating Rapid Cell Surface Morphological Changes in Mcf-7 Human Breast Cancer Cells
}

\author{
Julie E. Getz, * Marilee Sellers, * Stefanie R. Whish, * Cheryl A. Dyer* \\ * Department of Biological Sciences, College of Engineering and Natural Sciences, Northern \\ Arizona University, PO Box 5640 Flagstaff, AZ 86011
}

Decades of uranium (U) mining and milling activities in the Four Corners region of the U.S. has left hundreds of contaminated drinking water sources on the Navajo Nation [1]. Our laboratory's recent results suggest that $\mathrm{U}$ mimics $\mathrm{E} 2$ in vivo and in vitro to elicit estrogen receptor-dependant responses over several days. However there have not been studies conducted indicating that $U$ can mediate rapid, non-genomic dependent responses. The reproductive steroid, 17 $\beta$-estradiol (E2), induces responses that occur over hours to days or within minutes in estrogen receptor-dependent responses of Mcf-7 breast cancer cells [2].

In the present study we examined the morphological changes in Mcf-7 breast cancer cells within minutes of exposure to U. Mcf-7 cells were cultured in long term estrogen deprived (LTED) media, E2 had been absorbed to activated charcoal in repeated steps, resulting in a significantly increased sensitivity E2 treatment which was determined by measuring Mcf-7 cell proliferation with lowered E2 doses. The LTED cells were exposed to $28 \mu \mathrm{g} / \mathrm{L} \mathrm{U}$ or $60 \mu \mathrm{g} / \mathrm{L}$ diethylstilbestrol (DES), a potent synthetic form of estrogen, and incubated for 15,30 , or 60 minutes at $37^{\circ} \mathrm{C}$. The cells were processed for scanning electron microscopy (SEM) to visualize the effect $U$ had on cell surface morphology.

DES and U-treated cells rapidly increased the size, length and number of surface microvilli and induced membrane ruffling when compared to control cells (Figs 1-3). These results mimic morphological changes that have been reported in Mcf-7 cells exposed to estrogens [3]. The results also show that $\mathrm{U}$, in doses below the EPA safe drinking water level of $30 \mu \mathrm{g} / \mathrm{L}$, mimics E2-induced cell surface morphological responses.

Our results suggest that $U$ can mediate both long term and rapid estrogen receptor-dependant responses in vitro and provides evidence that environmental $U$ may be an endocrine disruptor potentially causing reproductive problems in the Navajo people [4].

References

[1] http://yosemite.epa.gov/r9/sfund/overview.nsf

[2] Song RX et al. Linkage of rapid estrogen action to MAPK activation by ER $\alpha$-Shc association and Shc pathway activation. Molecular Endocrinology (2002)16(1):116-127.

[3] Vic P et al. Effect of estradiol on the ultrastructure of the Mcf-7 human breast cancer cells in culture. Cancer Research (1982)42(2):667-673.

[4] This work was supported by grants from the Minority Student Development Program (Grant \# R25GM056931-07) and The Native American Cancer Research Partnership (Grant \# U54CA096320-04). 


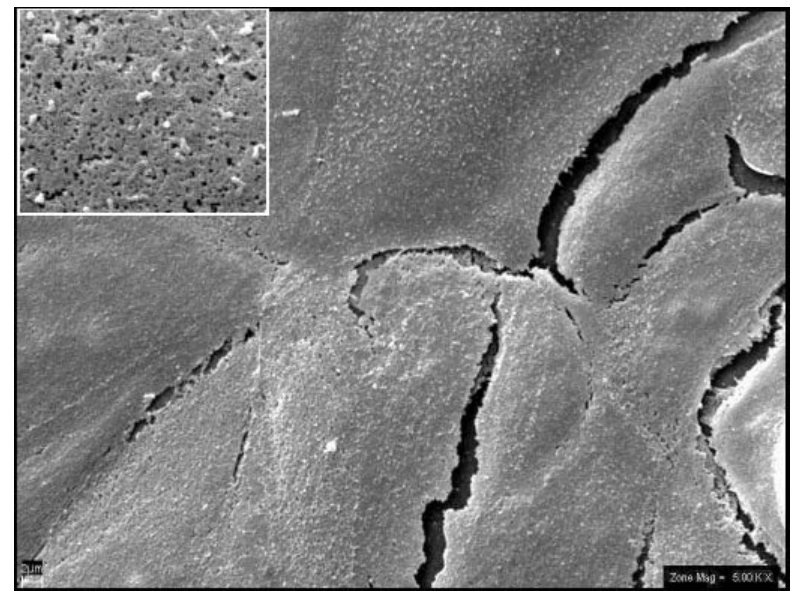

Fig. 1. Scanning Electron Micrograph of untreated MCF-7 Breast Cancer Cells. $5.00 \mathrm{Kx}, 20 \mathrm{kV}$. Inset, high magnification of microvilli, $30 \mathrm{Kx}$. (Bar, $10 \mu \mathrm{m})$.

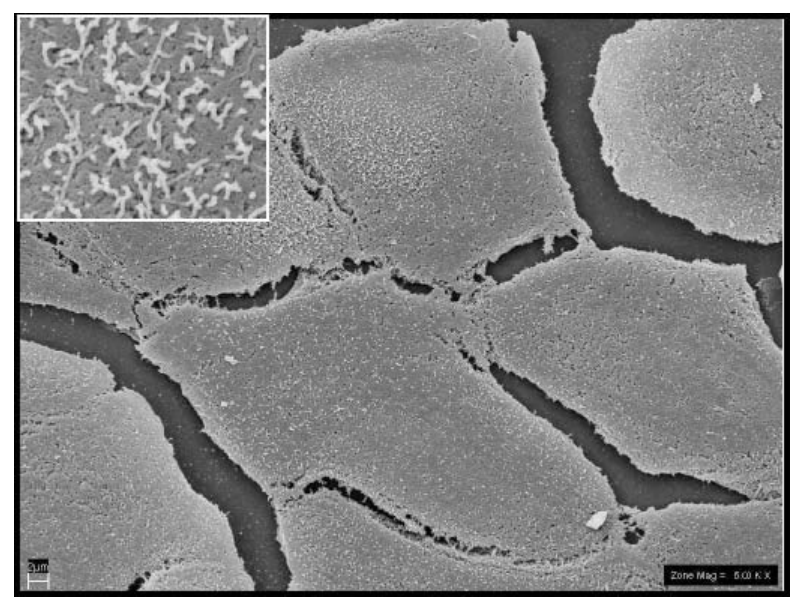

Fig. 2. Scanning Electron Micrograph of MCF-7 Breast Cancer Cells treated with $60 \mathrm{ug} / \mathrm{L}$ DES for 60 minutes. $5.00 \mathrm{Kx}, 20 \mathrm{kV}$. Inset, high magnification of microvilli, $30 \mathrm{Kx}$. (Bar, $10 \mu \mathrm{m})$.

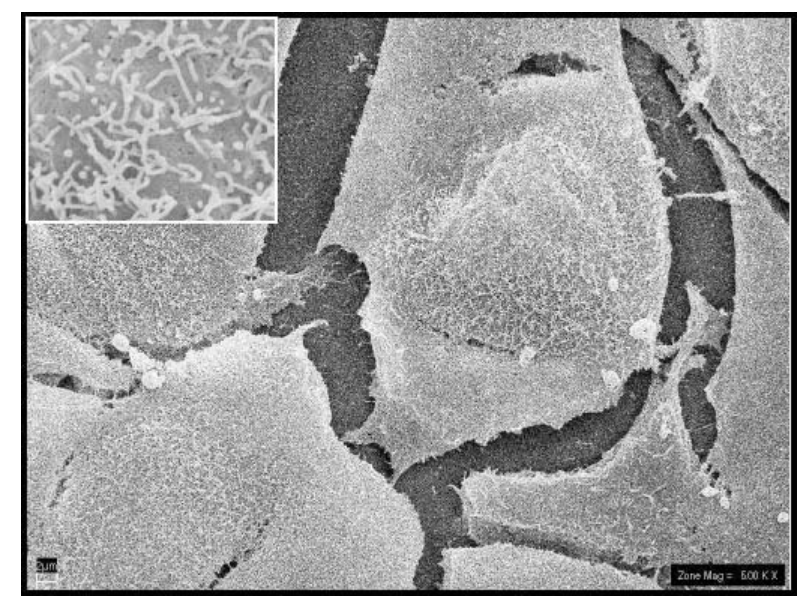

Fig. 3. Scanning Electron Micrograph of MCF-7 Breast Cancer Cells treated with 28 ug/L Uranium for 60 minutes. $5.00 \mathrm{Kx}, 20 \mathrm{kV}$. Inset, high magnification of microvilli, $30 \mathrm{Kx}$. (Bar, $10 \mu \mathrm{m})$. 